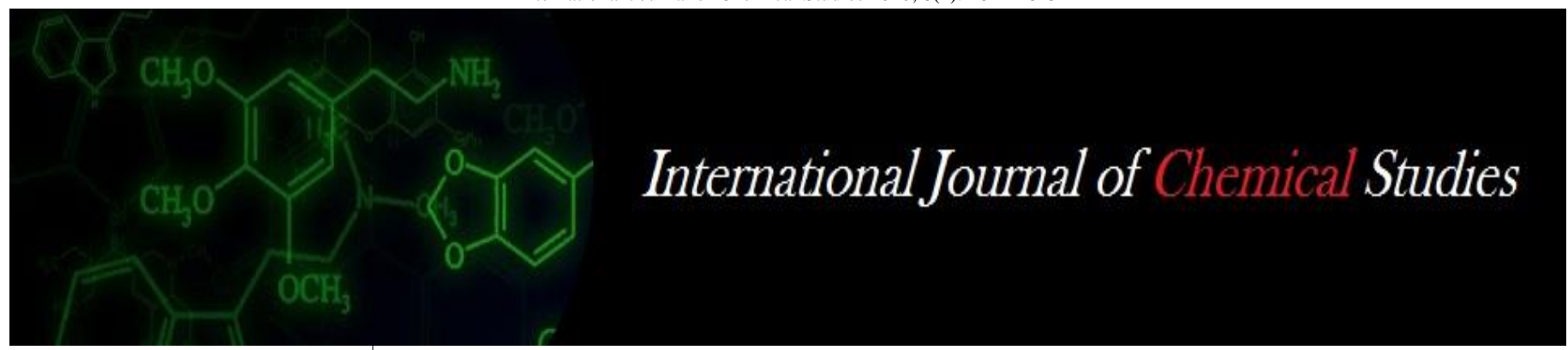

P-ISSN: 2349-8528

E-ISSN: 2321-4902

www.chemijournal.com

IJCS 2020; 8(2): 2821-2825

(C) 2020 IJCS

Received: 19-01-2020

Accepted: 21-02-2020

\section{SV Nalawade}

Ph.D. Scholar, Department of

Plant Pathology, N. M College of

Agriculture, Navsari

Agricultural University, Navsari,

Gujarat, India

\section{PR Patel}

Associate Professor, Department of Plant Pathology, ACHF,

Navsari Agricultural University,

Navsari, Gujarat, India

\section{VA Patil}

Assistant Professor, Main Rice

Research Centre, SWMRU,

Navsari Agricultural University,

Navsari, Gujarat, India
Corresponding Author:

\section{SV Nalawade}

Ph.D. Scholar, Department of

Plant Pathology, N. M College of Agriculture, Navsari

Agricultural University, Navsari, Gujarat, India

\section{Effect of weather parameters and sheath mite population on incidence and development of sheath rot disease of rice}

\author{
SV Nalawade, PR Patel and VA Patil
}

DOI: https://doi.org/10.22271/chemi.2020.v8.i2aq.9176

\begin{abstract}
Paddy (Oryza sativa L.) is the world's second most important cereal and staple food crop for people of south, south east and eastern Asia where 90 per cent of the world's rice is produced and consumed. In the present study, field experiment was conducted on epidemiological studies during Kharif 2018 and 2019 at Main Rice Research Centre Farm, NAU, Navsari on susceptible cultivar GR-11 at natural condition. Effect of different weather parameters and sheath mite population were explored by correlation and regression analysis to find out their contribution to incidence and development of the rice sheath rot disease. The maximum sheath rot incidence $(12.6 \%)$ and severity $(10.30 \%)$ were occurred when favorable weather conditions viz., maximum temperature in range of 29.0 and $36.9{ }^{\circ} \mathrm{C}$, minimum temperature in range of 20.3 and $24.7^{\circ} \mathrm{C}$, bright sunshine hours in range of 0.6 and 8.6 per day. Evening relative humidity in range of 50.0-97.6 per cent and sheath mite population in range of 0.95 to 7.95 mites per two $\mathrm{cm}$ rice leaf appeared. Correlation matrix was worked out and found that, significant highly positive correlation recorded with maximum temperature, bright sunshine hours and sheath mite infestation and played an important key role in the sheath rot development compared to other weather parameters. By employing stepwise regression equation model for sheath rot incidence revealed that at least $98 \%$ of variation in sheath rot incidence was explained by the function of weather parameters viz., minimum temperature and evening relative humidity and sheath mite infestation. Thus, weather parameters played a major role in sheath rot disease incidence in kharif season. Correlation matrix and step wise regression equation model established may be most reliable and useful for forecasting of the sheath rot disease of rice. The loss caused by the sheath rot can be saved by forewarning to the farmers and thereby controlling the same at the proper time.
\end{abstract}

Keywords: Sheath rot, sheath mite, forecasting, correlation and regression

\section{Introduction}

Rice (Oryza sativa L.) is one of the foremost cereal food crop grown in various agroecological zones in tropical and subtropical areas, especially in Asian countries such as India, China, Japan, Indonesia, Thailand, Pakistan, Bangladesh, North and South Korea, Myanmar, Philippines, Sri Lanka (Sharma et al., 2013) ${ }^{[17]}$. Asia is considered to be a "Rice Bowl" of the world and leader in rice production accounting for about 90 per cent of the world's production. The global production of rice has been estimated to be 463.52 million tonnes from an estimated area of 166.08 million hectares (FAO, 2017) ${ }^{[5]}$. India has the world's largest area under rice with 43.77 million hectares and is the second largest producer with 112.75 million tons next only to China with productivity of $2576 \mathrm{~kg} / \mathrm{ha}$ (Anonymous, 2017) ${ }^{[1]}$. Rice is cultivated in the country under four major ecosystems viz., irrigated, rainfed low-land, floodprone or deep water and rainfed upland (Prasad et al., 2012) ${ }^{[11]}$. In Gujarat, rice is cultivated on an area of 8.56 lakh hectares with total production of 18.90 lakh tonnes and productivity of about $2209 \mathrm{~kg} / \mathrm{ha}$ (Anonymous, 2017) ${ }^{[1]}$. The yield potential of rice in the state is low as compared to the national average which is attributed to a number of biotic factors. Among these, diseases of rice have been found the most devastating and widespread yield reducing factors that tremendously depreciate the crop qualitatively and quantitatively from nursery to harvest stage. Many fungal, bacterial and viral diseases and physiological disorders which occur on the rice crop at different stages of its growth, cause huge losses annually of 12 to 25 per cent of the total production (Rajan, 1987) ${ }^{[13]}$. 
Recently, minor disease sheath rot which was less significance earlier are now emerging as serious threats to rice production and shifted to the major one along with changing environment and cultivation practices and the use of susceptible varieties (Gupta et al., 2015) ${ }^{[6]}$. Severe outbreaks of sheath rot causing considerable yield losses were reported in India and South Asia. In India, Chakravarty and Biswas (1978) ${ }^{[3]}$ reported yield losses of 10-26 per cent (average estimate of $14 \%$ ) due to this disease. In severe cases, 100 per cent seed sterility and no panicle emergence were observed (Raina and Singh 1980, Kang and Rattan 1983, Pearce et al., 2001, Sakthivel, 2001 and Prasad et al., 2012) [12, 8, 10, 16, 11]. Estrada, et al. (1984) ${ }^{[4]}$ reported significantly fewer spikelets per panicle and lower 1000 grain weight from severely diseased panicles compared with healthy and estimated total yield loss due to sheath rot at 53 per cent. Bigirimana, et al. (2015) ${ }^{[2]}$ reported 85 per cent yield loss of rice due to sheath rot. Thus, sheath rot disease caused by fungus Sarocladium oryzae is one of the most prevalent and destructive fungal disease of rice. Availability of the susceptible host, sufficient inoculum and prevalence of favourable weather conditions play important role in the progress of disease development. The climate has a strong influence on the appearance of sheath rot epidemic; build up of inoculums and thereby dissemination of the disease. Because of regular occurrence of disease, yield losses up to 85 per cent and scanty information is available on the epidemiological aspects of this disease under south Gujarat agroclimatic conditions, present investigation was conducted with aim to know the effect of different weather parameters viz., maximum and minimum temperature, morning and evening relative humidity, total rain fall, rainy days, bright sunshine hours, wind speed and infestation of sheath mite population on infection and development of sheath rot disease of rice in south Gujarat condition.

\section{Materials and Methods}

A field trial on epidemiological studies was conducted during Kharif 2018 and 2019 at Main Rice Research Centre Farm, NAU, Navsari on susceptible cultivar GR-11. Transplanting was done in the month of July with plot size $20 \mathrm{~m} \times 20 \mathrm{~m}$ with spacing of $20 \mathrm{~cm} \times 15 \mathrm{~cm}$. No plant protection measures were taken up in this plot.

The weekly observations on weather parameters viz., maximum temperature $\left({ }^{\circ} \mathrm{C}\right)$, minimum temperature $\left({ }^{\circ} \mathrm{C}\right)$, morning relative humidity (\%), evening relative humidity $(\%)$, sunshine hours per day, rainfall $(\mathrm{mm})$ and wind speed $(\mathrm{km} / \mathrm{hr})$ were recorded from the meteorological observatory of NAU, Navsari during Kharif 2018 and 2019. The averages of the meteorological week (MW) wise of weather parameters with the average disease incidence during period of experimentation were used in the correlation along with the sheath mite infestation. Initially, the rice plants were observed daily for appearance of sheath rot disease. The 20 randomly selected plants on which the sheath rot appeared were tagged for further periodical observation. Likewise, the observations were made for sheath rot disease incidence and its intensity from the first appearance of disease till the physiological maturity of the crop at weekly interval. Per cent disease incidence and severity of sheath rot disease of rice were recorded by using following formula.

\section{$>$ Per cent disease incidence}

$$
\text { Disease incidence }(\%)=\frac{\text { Number of diseased plants }}{\text { Total number of plants observed }} \times 100
$$

\section{$>$ Per cent disease severity}

The disease severity was measured by adopting 0-9 scale (Table 1) by using standard evaluation system (SES) for rice developed by International Rice Research Institute, Philippines (IRRI, 2013) ${ }^{[7]}$. Further, the disease severity was calculated using the following formula.
Disease severity $(\%)=$
Sum of the individual disease ratings Total no. of leaves observed $x$ Maximum grade

Table 1: Disease severity rating scales for sheath rot of rice

\begin{tabular}{|c|c|c|}
\hline Score & Description & Disease reaction \\
\hline 0 & No lesion/ spot on flag leaf sheath. & Highly Resistant \\
\hline 1 & Spots visible on the tillers upon very careful examination (less than 1 per cent flag leaf sheath area covered). & Resistant \\
\hline 3 & Spots visible on the tillers upon careful examination (1 to 5 per cent flag leaf sheath area covered). & Moderately resistant \\
\hline 5 & Spots easily visible on tillers (6 to 25 per cent flag leaf sheath area covered). & Moderately susceptible \\
\hline 7 & Spots present on almost whole the tillers parts (26 to 50 per cent flag leaf sheath area covered). & Susceptible \\
\hline 9 & $\begin{array}{c}\text { Spots very common on whole tillers parts (51 to 100 per cent flag leaf sheath area covered) death of plants } \\
\text { common, reduced severe yield loss. }\end{array}$ & Highly susceptible \\
\hline
\end{tabular}

The observations on incidence of mites were recorded at fortnight interval, from each of 20 randomly selected plants. Observation on mite count was recorded from $2 \mathrm{~cm}$ area of the leaf sheath by using stereo binocular microscope.

Correlation matrix studies were carried out to determine the relationships between weather parameters and sheath mite infestation with progressive per cent disease incidence of sheath rot. The data was again subjected to stepwise regression equations by eliminating the non-significant factors and including only significant factors and regression equations were used to develop forewarning model for predicting disease incidence in advance

\section{Results and Discussion}

The experimental data on epidemiological factors viz., maximum and minimum temperature, morning and evening relative humidity, total rain fall, rainy days, bright sunshine hours, wind speed and infestation of sheath mite along with progressive sheath rot disease incidence and severity (average of two years i.e. from 2018 to 2019) in south Gujarat region was studied at weekly interval and is presented in table 2 .

\section{Progressive sheath rot disease incidence, severity and sheath mite population}

Sheath rot disease incidence, severity and sheath mite population were more during Kharif 2019 than in 2018 (Table 2 ). The weather during $31^{\text {st }}$ and $32^{\text {nd }}$ SMW played an important role in initiation of the sheath rot disease. During $34^{\text {th }}$ to $41^{\text {st }}$ standard weeks, there was very fast development of the disease due to congenial weather conditions. Hence, 
this period can be considered as a window period for the sheath rot of rice at Navsari condition.

In pooled result of two years, sheath rot disease incidence $(1.0 \%)$ and severity $(0.6 \%)$ was recorded in $33^{\text {th }}$ standard meteorological week (SMW) on susceptible variety GR-11. Since then, there was linear progress of the disease incidence $(2.6 \%)$ and severity (1.9\%) and was continuously increasing from $34^{\text {th }}$ SMW to a maximum incidence $(12.6 \%)$ and severity $(10.3 \%)$ in $42^{\text {th }}$ SMW in entire crop season. Sheath rot disease incidence (2.6 to $11.0 \%$ ) and severity (1.9 to $9.2 \%$ ) were reached at its peak period during $34^{\text {th }}$ SMW to $41^{\text {th }}$ SMW and hence this period was considered as window period for sheath rot disease incidence.

Similarly, sheath mite ( $S$. spinki) infestations that involved in development and favoring the sheath rot infection were recorded on $24^{\text {th }}$ August, 2018 i.e. $34^{\text {th }}$ standard meteorological week on susceptible variety GR-11. The progress of the sheath mite population was continuously increasing from $34^{\text {th }} \mathrm{SMW}$ ( 0.95 mite per $2 \mathrm{~cm}$ rice leaf) to a maximum infestation ( 7.85 mite per $2 \mathrm{~cm}$ rice leaf) in $41^{\text {th }}$ SMW and later sheath mite population decreased upto physiological maturity.

\section{Correlation coefficient studies between weather parameters along with sheath mite population and sheath rot incidence on cv.GR-11}

The correlation coefficients between the various meteorological parameters along with sheath mite infestation and biological parameters i.e. progress of sheath rot incidence at weekly interval were worked out by simple correlation technique.

The disease started appearing after booting stage of the crop and epidemiological studies were performed right from transplanting to harvesting of the crop. The incidence of sheath rot disease on susceptible cv. GR-11 was recorded at weekly interval and corresponding weather parameters in crop growing season are presented in table 3 and figure 1.

The pooled data of two years revealed that, the disease gradually increased and progressed up to the harvesting stage continuously. Sheath rot of rice was initiated in $33^{\text {th }}$ SMW. Previous two weeks $31^{\text {th }}$ and $32^{\text {th }}$ SMW were recorded maximum temperature i.e., 29.3 and $29.6^{\circ} \mathrm{C}$, minimum temperature i.e., 23.9 and $24.1^{\circ} \mathrm{C}$, morning relative humidity i.e., 84.1 and 94.0 per cent, evening relative humidity i.e., 89.4 and 86.2 per cent. Whereas, bright sunshine hours i.e., 0.5 and $0.8 \mathrm{hr}$., rainy days i.e., 3.5 and 3.5 days, total rainfall i.e., 192.5 and $89.0 \mathrm{~mm}$ and wind speed i.e., 12.6 and 6.4 $\mathrm{km} / \mathrm{hrs}$, respectively. These conditions highly favored for initiation and development of the sheath rot disease.

First symptoms of sheath rot disease incidence were observed on $33^{\text {th }}$ SMW and more progressive during $33^{\text {rd }}, 34^{\text {th }}, 35^{\text {th }}$ and $36^{\text {th }} \mathrm{SMW}$, respectively when favorable weather conditions viz., maximum temperature i.e., 30.0, 29.8, 30.5 and $30.9^{\circ} \mathrm{C}$, minimum temperature i.e., 23.8, 23.1, 23.3 and $22.6{ }^{\circ} \mathrm{C}$, morning relative humidity i.e., 94.5, 95.5, 95.2 and 94.1 per cent, evening relative humidity i.e., 84.9, 82.5, 83.1 and 82.5 per cent. As well as bright sunshine hours i.e., 1.6, 4.6, 2.7 and 3.3 hrs, rainy days i.e., $4.5,3.5,4.0$ and 4.5 days, total rainfall i.e., 39.5, 65.0, 118.0 and $126.0 \mathrm{~mm}$ and wind speed i.e., 3.3, 5.3, 5.7 and $4.1 \mathrm{~km} / \mathrm{hr}$, respectively. Sheath mite infestation progressively increased i.e., 0.0, 0.95, 1.98 and 3.08 , respectively.

Correlation matrix was worked out and significant correlation was noticed between meteorological parameters, sheath mite infestation on progressive per cent disease incidence of sheath rot during entire both years in Kharif seasons on variety GR11 (Table 3). The significantly highly positive correlation was recorded with maximum temperature $(\mathrm{r}=0.658 * *)$ bright sunshine hours $(\mathrm{r}=0.754 * *)$ and sheath mite infestation $\left(\mathrm{r}=0.967^{* *}\right)$. However, significant highly negative correlation with minimum temperature $(\mathrm{r}=-832 * *)$, evening relative humidity $(\mathrm{r}=-0.801 * *)$, rainy days $(\mathrm{r}=-0.577 * *)$ and wind speed $\left(\mathrm{r}=-0.736^{* *}\right)$, whereas, significantly negative correlation was found with morning relative humidity ( $\mathrm{r}=-$ $\left.0.495^{*}\right)$ and total rainfall $\left(\mathrm{r}=-485^{*}\right)$. Maximum temperature, bright sunshine hours and sheath mite infestation were playing an important key role in the sheath rot development compared to other weather parameters.

\section{Stepwise regression equation between sheath rot incidence, weather parameters and sheath mite population on cv.GR-11 at Navsari}

The regression coefficient based on stepwise regression analysis for nine independent (eight weather and one sheath mite infestation) variables and to identify critical and much contributing weather variable (s) separately towards the dependent variables i.e., sheath rot disease is worked out and presented. The result indicated that, R-value was high 0.98 indicating a strong association between per cent disease incidence and sheath mite infestation and weather parameters viz., minimum temperature and evening relative humidity. The $\mathrm{R}^{2}$ value was found to be high $(97.30 \%)$. This clearly indicated that at least $98 \%$ of variation in sheath rot incidence was explained by the function of sheath mite infestation and weather parameters viz., minimum temperature and evening relative humidity. The regression model was elaborated with the best fitted stepwise regression equation shown as under:

\section{$\hat{\mathrm{Y}}=39.366+0.691 \mathrm{ShM}-1.131 \mathrm{Tmin}-0.134 \mathrm{RH}-\mathrm{II}(\mathrm{R} 2=97.30)$}

Where,

$\hat{\mathrm{Y}}=\quad$ Predicted disease incidence, $\mathrm{a}=$ Intercept, ShM = Sheath mite, Tmin $=$ Minimum temperature $\left({ }^{\circ} \mathrm{C}\right), \mathrm{RH}-\mathrm{II}=$ Evening relative humidity $(\%)$.

It is very clear from the present study that, the maximum sheath rot incidence were observed when favorable weather conditions viz., maximum temperature in range of 29.0 and $36.9{ }^{\circ} \mathrm{C}$, minimum temperature in range of 20.3 and $24.7^{\circ} \mathrm{C}$, bright sunshine hours in range of 0.6 and 8.6 per day. Evening relative humidity in range of 50.0-97.6 per cent and sheath mite population in range of 0.95 to 7.95 mites per two $\mathrm{cm}$ rice leaf appeared. These conditions were prevailing during $34^{\text {th }}$ $42^{\text {th }}$ standard meteorological weeks when the crop was in booting phase to maturity stage. This caused severe loss and hence considered as major constraint in economic production of the rice crop in the south Gujarat. Thus, weather parameters played a major role in sheath rot disease incidence in kharif season. Correlation matrix and step wise regression equation model established may be most reliable and useful for forecasting of the sheath rot disease of rice. The loss caused by the sheath rot can be saved by forewarning to the farmers and thereby controlling the same at the proper time. Similar line of results were also reported by Koshal (2001) ${ }^{[9]}$ who found the effect of weather parameters (mean temperature, mean relative humidity and rainfall) on disease index of sheath rot disease and observed that disease had significant but negative correlation with respect to temperature and relative humidity Whereas, a non significant correlation was observed between disease index and rainfall. 
Maximum disease development was observed at maximum temperature range of $32.5^{\circ} \mathrm{C}$ and $32.8{ }^{\circ} \mathrm{C}$, where as minimum temperature ranged between $18.11{ }^{\circ} \mathrm{C}$ and $20.4{ }^{\circ} \mathrm{C}$. During this period, minimum and maximum relative humidity ranged between 32.5 and 83.0 per cent. Also average temperature range of $25.13^{\circ} \mathrm{C}$ to $25.45{ }^{\circ} \mathrm{C}$ and relative humidity of 55.64 to 57.75 per cent were found to favour rapid disease development in the month of October with disease index of 24, 63 and 183 per cent in cultivars Bas-370, PR-106 and lET-1410, respectively.

Reddy et al. (2001) ${ }^{[15]}$ indicated that the sheath rot incidence of rice was more in Kharif season than in Rabi season. Correlation analysis has shown that relative humidity, temperature and sunshine are having positive correlation with disease index, Whereas, Negative influence of minimum temperature was significant on all the 22 plantings Whereas, maximum temperature had significant positive influence on $16^{\text {th }}$ July, $16^{\text {th }}$ August plantings of Kharif and on $16^{\text {th }}$ December and $1^{\text {st }}$ January plantings of Rabi and sunshine was also positive correlated with DI, but its influence was significant on $1^{\text {st }}$ June, $16^{\text {th }}$ July, $1^{\text {st }}$ August, $16^{\text {th }}$ August, $1^{\text {st }}$ January to $16^{\text {th }}$ February plantings only.

Ravat and Basu (2017) ${ }^{[14]}$ reported that the incidence of sheath rot during booting to dough stage of rice favours temperature and relative humidity ranged from $23.07^{\circ} \mathrm{C}$ to $26.5^{\circ} \mathrm{C}$, from 73.85 to 87.40 per cent, respectively.

\section{Acknowledgements}

Authors are thankful to Hon'ble Vice Chancellor, Director of Research, Dean and Principal, N. M. COA and ASPEE, ACHF, Head of Department, Department of Plant Pathology and In charge, Main Rice Research Centre, SWMRU, Navsari Agriculture University, Navsari for their valuable suggestions and kind cooperation for conducting this experiment.

Table 2: Effect of weather parameters and sheath mite population on sheath rot disease incidence and severity on cv. GR-11 in pooled

\begin{tabular}{|c|c|c|c|c|c|c|c|c|c|c|c|c|c|}
\hline $\begin{array}{c}\text { Sr. } \\
\text { No. }\end{array}$ & $\begin{array}{c}\text { Std. } \\
\text { Metrological } \\
\text { Week }\end{array}$ & $\begin{array}{c}\text { Period of } \\
\text { Observation }\end{array}$ & $\begin{array}{c}\text { Temp. } \\
\text { Max. } \\
(\text { oC) }\end{array}$ & $\begin{array}{c}\text { Temp. } \\
\text { Min. } \\
(\text { oC) }\end{array}$ & $\begin{array}{c}\text { Morning } \\
\text { relative } \\
\text { humidity } \\
(\%)\end{array}$ & \begin{tabular}{|c|}
$\begin{array}{c}\text { Evening } \\
\text { relative } \\
\text { humidity } \\
(\%)\end{array}$ \\
\end{tabular} & \begin{tabular}{|c|} 
Bright \\
Sunshine \\
Hrs/day
\end{tabular} & $\begin{array}{c}\text { Rainy } \\
\text { Days } \\
\text { Nos. }\end{array}$ & $\begin{array}{c}\text { Total } \\
\text { Rainfall } \\
(\mathbf{m m} / \text { week })\end{array}$ & $\begin{array}{c}\text { Wind } \\
\text { speed } \\
(\mathbf{k m} / \mathbf{h r})\end{array}$ & \begin{tabular}{|c|} 
Sheath \\
mite/ \\
$2 \mathrm{~cm}$ leaf \\
sheath \\
\end{tabular} & $\begin{array}{c}\text { Disease } \\
\text { Incidence } \\
(\%)\end{array}$ & $\begin{array}{c}\text { Disease } \\
\text { Severity } \\
(\%)\end{array}$ \\
\hline 1 & 23 & 3-9 June & 34.9 & 27.4 & 90.4 & 69.5 & 7.0 & 0.5 & 4.2 & 5.9 & 0.0 & 0.0 & 0.0 \\
\hline 2 & 24 & 10-16 June & 34.1 & 25.9 & 89.5 & 77.9 & 4.3 & 2.5 & 34.5 & 6.4 & 0.0 & 0.0 & 0.0 \\
\hline 3 & 25 & 17-23 June & 33.4 & 25.4 & 90.9 & 74.4 & 6.3 & 0.5 & 18.0 & 5.8 & 0.0 & 0.0 & 0.0 \\
\hline 4 & 26 & 24-30 June & 31.4 & 24.1 & 96.6 & 83.1 & 3.4 & 3.5 & 170.8 & 5.8 & 0.0 & 0.0 & 0.0 \\
\hline 5 & 27 & 1-7 July & 30.2 & 23.9 & 97.9 & 94.7 & 1.7 & 5.0 & 239.5 & 5.4 & 0.0 & 0.0 & 0.0 \\
\hline 6 & 28 & 8-14 July & 30.1 & 24.3 & 97.2 & 90.7 & 1.2 & 5.0 & 318.0 & 3.7 & 0.0 & 0.0 & 0.0 \\
\hline 7 & 29 & 15-21 July & 29.9 & 23.8 & 95.1 & 86.7 & 2.7 & 4.5 & 175.5 & 3.8 & 0.0 & 0.0 & 0.0 \\
\hline 8 & 30 & 22-28 July & 30.4 & 24.8 & 90.9 & 87.3 & 1.2 & 2.5 & 63.5 & 7.4 & 0.0 & 0.0 & 0.0 \\
\hline 9 & 31 & 29 July -4 Aug & 29.3 & 23.9 & 84.1 & 89.4 & 0.5 & 3.5 & 192.5 & 12.6 & 0.0 & 0.0 & 0.0 \\
\hline \begin{tabular}{|l|}
10 \\
\end{tabular} & 32 & 5-11 Aug. & 29.6 & 24.1 & 94.0 & 86.2 & 0.8 & 3.5 & 89.0 & 6.4 & 0.0 & 0.0 & 0.0 \\
\hline \begin{tabular}{|l|}
11 \\
\end{tabular} & 33 & 12-18 Aug. & 30.0 & 23.8 & 94.5 & 84.9 & 1.6 & 4.5 & 39.5 & 3.3 & 0.0 & 1.0 & 0.6 \\
\hline \begin{tabular}{|l|}
12 \\
\end{tabular} & 34 & 19-25 Aug. & 29.8 & 23.1 & 95.5 & 82.5 & 4.6 & 3.5 & 65.0 & 5.3 & 0.95 & 2.6 & 1.9 \\
\hline 13 & 35 & 26-Aug -1 Sept & 30.5 & 23.3 & 95.2 & 83.1 & 2.7 & 4.0 & 118.0 & 5.7 & 1.98 & 4.0 & 2.8 \\
\hline 14 & 36 & 2-8 Sept. & 30.9 & 22.6 & 94.1 & 82.5 & 3.3 & 4.5 & 126.0 & 4.1 & 3.08 & 4.8 & 3.9 \\
\hline \begin{tabular}{|l|}
15 \\
\end{tabular} & 37 & 9-15 Sept. & 31.6 & 22.6 & 93.7 & 80.0 & 4.4 & 2.0 & 113.5 & 3.5 & 4.15 & 6.2 & 5.0 \\
\hline \begin{tabular}{|l|}
16 \\
\end{tabular} & 38 & 16-22 Sept. & 32.6 & 22.3 & 92.0 & 70.8 & 5.6 & 2.5 & 61.0 & 2.7 & 5.15 & 7.8 & 5.6 \\
\hline \begin{tabular}{|l|}
17 \\
\end{tabular} & 39 & 23-29 Sept. & 32.9 & 22.1 & 92.3 & 68.0 & 8.1 & 1.5 & 27.0 & 2.1 & 6.20 & 8.4 & 6.4 \\
\hline 18 & 40 & 30 Sept-6 Oct. & 35.0 & 22.3 & 86.9 & 61.6 & 8.6 & 1.0 & 16.0 & 0.7 & 7.10 & 9.6 & 7.5 \\
\hline \begin{tabular}{|l|}
19 \\
\end{tabular} & 41 & $7-13$ Oct & 36.7 & 21.8 & 87.9 & 58.5 & 8.4 & 0.0 & 0.0 & 0.7 & 7.85 & 11.0 & 9.2 \\
\hline \begin{tabular}{|l|l|}
20 \\
\end{tabular} & 42 & $14-20 \mathrm{Oct}$ & 36.5 & 20.6 & 82.0 & 61.2 & 8.6 & 0.0 & 0.0 & 1.1 & 5.35 & 12.6 & 10.3 \\
\hline
\end{tabular}

Table 3: Correlation matrix between sheath rot incidence and weather parameters and sheath mite population two year pooled

\begin{tabular}{|c|c|c|c|c|c|c|c|c|c|c|}
\hline Variable & $\begin{array}{c}\begin{array}{c}\text { Sheath rot } \\
\text { incidence } \\
(\%)\end{array} \\
\end{array}$ & $\begin{array}{c}\text { Temperature } \\
\text { Max. } \\
\left({ }^{\circ} \mathbf{C}\right)\end{array}$ & $\begin{array}{c}\text { Temperature } \\
\text { Min. } \\
\left({ }^{\circ} \mathrm{C}\right)\end{array}$ & $\begin{array}{c}\text { Morning } \\
\text { relative } \\
\text { humidity } \\
(\%)\end{array}$ & $\begin{array}{c}\text { Evening } \\
\text { relative } \\
\text { humidity } \\
(\%)\end{array}$ & $\begin{array}{c}\text { Bright } \\
\text { sunshine } \\
\text { hours per } \\
\text { day }\end{array}$ & $\begin{array}{c}\text { Rainy } \\
\text { days } \\
\text { Nos. }\end{array}$ & $\begin{array}{c}\text { Total } \\
\text { rainfall } \\
\text { mm/ } \\
\text { week }\end{array}$ & $\begin{array}{c}\text { Wind } \\
\text { speed } \\
\text { Km/hrs }\end{array}$ & $\begin{array}{c}\text { Sheath } \\
\text { mite/ } \\
\text { 2cm leaf } \\
\text { sheath }\end{array}$ \\
\hline $\begin{array}{c}\text { Sheath rot } \\
\text { incidence }(\%)\end{array}$ & 1.000 & 0.658 & -0.832 & -0.495 & -0.801 & 0.754 & -0.577 & -0.485 & -0.736 & 0.967 \\
\hline $\begin{array}{l}\text { Temperature } \\
\text { Max. }\left({ }^{\circ} \mathrm{C}\right)\end{array}$ & 0.658 & 1.000 & -0.193 & -0.635 & -0.917 & 0.895 & -0.878 & -0.677 & -0.557 & 0.683 \\
\hline $\begin{array}{l}\text { Temperature } \\
\text { Mini. }\left({ }^{\circ} \mathrm{C}\right)\end{array}$ & -0.832 & -0.193 & 1.000 & 0.232 & 0.390 & -0.352 & 0.128 & 0.105 & 0.587 & -0.768 \\
\hline $\begin{array}{c}\text { Morning relative } \\
\text { humidity }(\%)\end{array}$ & -0.495 & -0.635 & 0.232 & 1.000 & 0.666 & -0.501 & 0.709 & 0.543 & 0.011 & -0.471 \\
\hline $\begin{array}{c}\text { Evening relative } \\
\text { humidity }(\%)\end{array}$ & -0.801 & -0.917 & 0.392 & 0.666 & 1.000 & -0.944 & 0.886 & 0.768 & 0.605 & -0.823 \\
\hline $\begin{array}{c}\text { Bright } \\
\text { Sunshine hrs/day }\end{array}$ & 0.754 & 0.895 & -0.352 & -0.501 & -0.944 & 1.000 & -0.848 & -0.703 & -0.661 & 0.767 \\
\hline Rainy Days & -0.577 & -0.878 & 0.128 & 0.709 & 0.886 & -0.848 & 1.000 & 0.781 & 0.345 & -0.601 \\
\hline Total Rainfall & -0.485 & -0.677 & 0.105 & 0.543 & 0.786 & -0.703 & 0.781 & 1.000 & 0.348 & -0.475 \\
\hline Wind speed & -0.736 & -0.557 & 0.587 & 0.011 & 0.605 & -0.661 & 0.345 & 0.348 & 1.000 & -0.732 \\
\hline Sheath mite & 0.967 & 0.683 & -0.768 & -0.471 & -0.823 & 0.767 & \begin{tabular}{|l|}
-0.601 \\
\end{tabular} & -0.475 & -0.732 & 1.000 \\
\hline
\end{tabular}




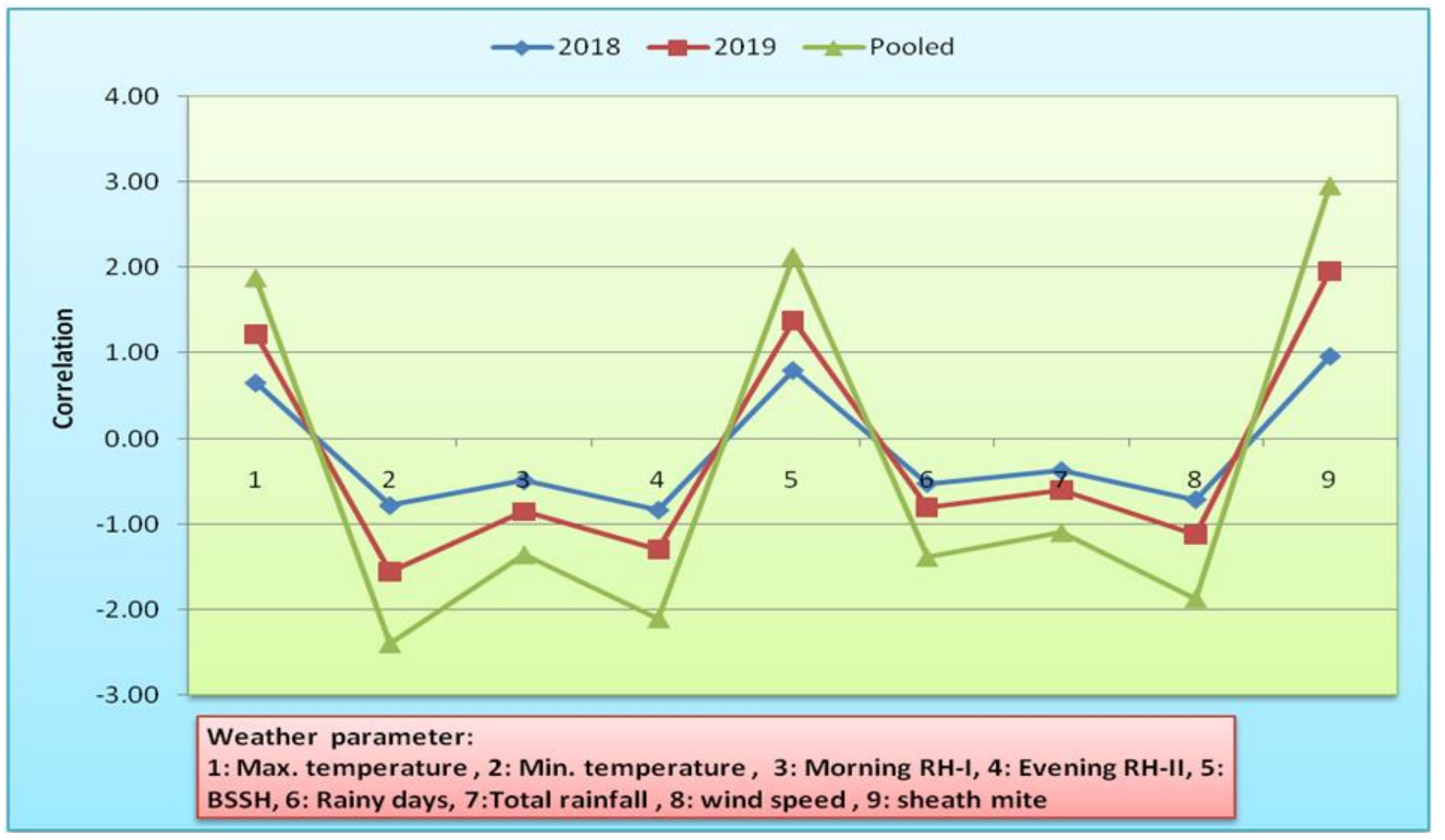

Fig 1: Graphical presentation on correlation matrix between sheath rot incidence with weather parameters and sheath mite

\section{References}

1. Anonymous, 2017. www.indiastat.com-2017.

2. Bigirimana VD, Hua GK, Nyamangyoku OI, Hofte M. Rice sheath rot: An emerging ubiquitous destructive disease complex. Frontier in Plant Science 2015, 1-16.

3. Chakravarty DK, Biswas S. Estimation of yield loss in rice affected by sheath rot. Plant Disease Reporter. 1978; 62(3):226-227.

4. Estrada BA, Torres CQ, Bonman JM. Effect of sheath rot on some yield components. International Rice Research Newsletter 1984; 9(2):14.

5. FAOSTAT Agriculture data. http://www.fao.org and http://faostat.fao.org/ (last update 2017). Rome, Italy

6. Gupta AK, Solanki IS, Bashyal BM, Singh Y, Srivastava K. Bakanae of rice an emerging disease in Asia. The Journal of Animal and Plant Sciences. 2015; 25(6):14991514.

7. IRRI. Standard of evaluation system for rice. The international rice testing programme. Genetic resources centre, International Rice Research Institute. Manilla, Philippines 2013, 20-21.

8. Kang MS, Rattan GS. Sheath rot in the Punjab, India. International Rice Research Newsletter. 1983; 8(3):7-8.

9. Koshal VK. Studies on epidemiology and chemical management of sheath rot of rice (Oryza sativa L.). M. Sc. (Agri.) thesis submitted, Sher-e-Kashmir University of Agricultural Sciences and Technology, Jammu (J\&K) 2001, 32

10. Pearce DA, Bridge PD, Hawksworth DL. Species concept in Sarocladium, the causal agent of sheath rot in rice and bamboo blight. Major fungal diseases of rice, recent advances, Eds S. Sreenivasaprasad and R. Johnson, Kluwer Academic Publishes. 2001, 285-292.

11. Prasad MS, Ladha Laxmi D, Prakasam V, Laha GS, Krishnaveni D, Viraktamath BC. Disease management in rice - A Ready Reckoner. Technical bulletin No. 60.
Directorate of Rice Research, Rajendranagar, Hyderabad. 2012, 1-15

12. Raina GL, Singh G. Sheath rot outbreak in Punjab. International Rice Research, News letter. 1980; 5(1):16.

13. Rajan CPD. Estimation of yield losses due to sheath blight of rice. Indian Phytopathology. 1987; 40:174-177.

14. Ravat VK, Basu A. Current status of fungal diseases on Swarna cultivar (MTU 7029) of rice in gangetic alluvial zone of West Bengal, India. International Journal of Current Microbiology and Applied Sciences, 2017; 6(9):2069-2080.

15. Reddy MM, Reddy CS, Reddy AGR. Influence of weather parameters and insect pest populations on incidence and development of sheath rot of rice. Indian Phytopathology. 2001; 54(2):179-184.

16. Sakthivel N. Sheath rot disease of rice: current status and control strategies, in major fungal diseases of rice: recent advances, eds S. Sreenivasaprasad and R. Johnson (Dordrecht: Springer), 2001, 271-283.

17. Sharma L, Nagrale DT, Singh SK, Sharma KK, Sinha AP. A study on fungicide potential and incidence of sheath rot of rice caused by Sarocladium oryzae (Sawada). Journal of Applied and Natural Science. 2013; 5(1):24-29. 